\title{
Analysis of apoptosis in the preimplantation bovine embryo using TUNEL
}

\author{
A. T. Byrne' ${ }^{1}$ J. Southgate ${ }^{2}$, D. R. Brison ${ }^{3}$ and H. J. Leese ${ }^{1}$ \\ ${ }^{1}$ Department of Biology, University of York, PO Box 373, York YO10 5YW, UK; ${ }^{2} I C R F$ Cancer Medicine Research Unit, \\ St James's University Hospital, Leeds LS9 7TF, UK; and 'Department of Reproductive Medicine, St Mary's Hospital, Whitworth Park, \\ Manchester M13 0JH, UK
}

\begin{abstract}
The occurrence of cell death by apoptosis was examined in blastocyst and preblastocyst stage bovine embryos. Zygotes were obtained by in vitro maturation and in vitro fertilization of oocytes from abattoir derived ovaries. Two-cell to hatched blastocyst stage embryos were stained with propidium iodide to label all nuclei and by terminal deoxynucleotidyl transferase (TdT)-mediated d-UTP nick end-labelling (TUNEL) to label apoptotic nuclei, and were analysed by epifluorescent and confocal microscopy. Apoptosis was first observed at the 9-16-cell stage of development, decreasing at the morula stage before increasing at the blastocyst stage. Apoptotic dead cell index in day 7 blastocysts was negatively correlated with the total number of cells; the percentage of dead cells ranged from approximately 1 to $10 \%$ and occurred predominantly within the inner cell mass. In addition, apoptotic dead cell index was significantly higher $(P<0.05)$ in blastocysts cultured (from the two-cell stage) in the presence of $10 \%$ fetal bovine serum compared with those developed in serum-free medium. Embryos selected for early cleavage at $<29 \mathrm{~h}$ after fertilization and cultured together until the blastocyst stage showed a significantly lower rate of apoptosis $(P<0.01)$ compared with slower cleaving embryos.
\end{abstract}

\section{Introduction}

The presence of dead cells in the preimplantation mammalian embryo was first described by Potts and Wilson (1967). Since then it has become increasingly apparent that these cells die by apoptosis (Kerr et al., 1972), a form of programmed cell death. This process ensures the regulation of cell populations and cell lineages in all major mammalian systems and has many specialized functions during development.

Light microscope and ultrastructural studies of blastocysts from many species, including mice, cows, baboons, rhesus monkeys and humans, have described dead and dying cells within the embryo (El-Shershaby and Hinchliffe, 1974; Copp, 1978; Hurst et al., 1978; Enders and Schlafke, 1981; Enders et al., 1982; Lopata et al., 1982; Mohr and Trounson, 1982; Enders et al., 1990; Hardy et al., 1996). Differential labelling of trophectoderm and inner cell mass (ICM) cells with polynucleotide specific fluorochromes has been used in mouse, human, rat, rabbit and pig embryos to describe the spatial occurrence of apoptotic cell death (Handyside and Hunter, 1986; Papaioannou and Ebert, 1988; Hardy et al., 1989; Pampfer et al., 1990a,b; Giles and Foote, 1995; Hardy and Handyside, 1996; Lea et al., 1996; Brison and Schultz, 1997). Further assessment of embryo apoptotic cell death has been carried out using the terminal deoxynucleotidyl

Received 13 October 1998. transferase (TdT)-mediated d-UTP nick end-labelling technique (TUNEL). This method facilitates the analysis of nuclear DNA fragmentation in situ. Moreover, cells undergoing the early stages of apoptosis are preferentially labelled by the TUNEL reaction (Gavrieli et al., 1992). This technique has proved useful in the quantitative measurement of cell death in mouse and human embryos in which only a few cells are present and therefore small amounts of apoptotic DNA (Jurisicova et al., 1996; Pampfer et al., 1997; Brison and Schultz, 1997, 1998).

In most species apoptosis is largely confined to the ICM lineage; for example, in mouse day 4 and day 5 blastocysts freshly flushed from the reproductive tract, the percentage of dead cells in the ICM is of the order of $10 \%$, whereas in the trophectoderm is <3\% (Hardy and Handyside, 1996). Apoptosis in the ICM may regulate this cell population, since the number of ICM cells reaches a plateau in later stage blastocysts without a decrease in mitotic cell division (Handyside and Hunter, 1986). Furthermore, redundant ICM cells that retain trophectoderm potential after blastocyst expansion may be removed by apoptosis (Handyside and Hunter, 1986; Pierce et al., 1989). Thus, it is likely that blastocyst stage apoptosis acts to eliminate cells that are damaged, are in excess, are no longer required or are developmentally incompetent. Cellular 'quality control' within the ICM is critical since this lineage forms the fetus and contains the germline.

A distinction can be made between apoptosis in mor- 
phologically normal in vitro produced (IVP) embryos and abnormal fragmenting (that is, dying) embryos. Apoptosis has not been observed before the blastocyst stage in mouse embryos that are developing normally, although the apoptotic machinery is probably present throughout preimplantation development. When extracellular signals are blocked using the protein kinase inhibitor staurosporine, cells from mouse blastocysts and four-cell stage embryos all undergo apoptosis showing characteristic physiological and biochemical features (Weil et al., 1996). Apoptosis may play a role in eliminating abnormal or defective embryos as early as the first cell cycle in mice (Jurisicova et al., 1998; Warner et al., 1998) and the second cell cycle in humans (Jurisicova et al., 1996). This first wave of apoptosis may be related to activation of the embryonic genome, the major event of which occurs at the two-cell stage in mice and the four-cell stage in humans. Sible et al. (1997) obtained evidence in Xenopus for the presence of a maternally regulated developmental checkpoint at the stage of embryonic genome activation, which can trigger apoptosis.

There are no reports of apoptosis in the bovine preimplantation embryo. This species is of particular interest since the embryonic genome is activated relatively late in development at the 9-16-cell stage (Frei et al., 1989). The effect of apoptosis on allocation of cells to the trophectoderm or ICM lineages may also be important since an aberrant trophectoderm:ICM cell ratio may be a contributory factor in the aetiology of the enlarged offspring syndrome in domestic animals (Thompson et al., 1995). One factor that is thought to predispose to fetal oversize after transfer of IVP embryos, is the presence of serum in the culture medium. Little is known of the effect on in vitro derived bovine embryos of environmental factors, such as embryo culture technique and the addition of serum to medium, which may play a role in regulating cell death.

The aims of the present study were: (i) to describe the timing and distribution of apoptosis in in vitro derived bovine embryos; (ii) to assess the effect of culturing zygotes to the blastocyst stage in the presence of serum; and (iii) to investigate whether the selection and culturing together of embryos that have cleaved $<29 \mathrm{~h}$ after fertilization affects the onset and incidence of apoptosis compared with slower cleaving embryos.

A preliminary account of this work has been presented (Byrne et al., 1998).

\section{Materials and Methods}

\section{Production of embryos in vitro}

Bovine ovaries were collected from an abattoir and transported to the laboratory in PBS at approximately $24-26^{\circ} \mathrm{C}$. The maximum time from slaughter to oocyte collection was $8 \mathrm{~h}$. Cumulus-oocyte complexes (COC) were recovered by initial ovarian dissection, followed by slashing of $1-5 \mathrm{~mm}$ follicles using a sterile scalpel and the subsequent release of oocytes. The COC were collected into Hepesbuffered TCM-199 medium supplemented with $10 \mu \mathrm{g}$ heparin $\mathrm{ml}^{-1}$ (Sigma, Poole) and $0.4 \%(\mathrm{w} / \mathrm{v}$ ) BSA (Sigma).
The morphology of COC was assessed and only those with a compact non-atretic cumulus oophorus and evenly graduated cytoplasm were selected for maturation. All oocytes were washed twice in Hepes-buffered TCM-199 supplemented with $0.4 \%$ BSA, washed once in maturation medium, placed in $500 \mu \mathrm{l}$ wells of the same medium and incubated for $24 \mathrm{~h}$ at $39^{\circ} \mathrm{C}$ under humidified $5 \% \mathrm{CO}_{2}$ in air. The medium used for maturation was TCM-199 supplemented with $10 \%$ fetal bovine serum (FBS) and $10 \mathrm{ng}$ epidermal growth factor (EGF) $\mathrm{ml}^{-1}$ (Sigma).

Fertilized oocytes were prepared according to the method of Thompson et al. (1992). Spermatozoa were prepared from frozen-thawed semen samples from a single bull of proven fertility. Semen was thawed in a waterbath at $37^{\circ} \mathrm{C}$, layered on a discontinuous Percoll (Pharmacia Biotech, St Albans) gradient (45:90) and centrifuged at $2100 \mathrm{~g}$ for $25 \mathrm{~min}$. The motile sperm pellet was washed in Hepes-buffered modified $\mathrm{Ca}^{2+}$-free Tyrode-albumin-sodium lactate-sodium pyruvate (TALP) medium (Lu et al., 1987) and resuspended in bicarbonate-buffered fertilization TALP medium with $10 \mu \mathrm{g}$ heparin $\mathrm{ml}^{-1}, 600 \mu \mathrm{g}$ penicillamine $\mathrm{ml}^{-1}$ and $220 \mu \mathrm{g}$ hypotaurine $\mathrm{ml}^{-1}$. The sperm concentration was adjusted to give a final concentration of $1-2 \times 10^{6} \mathrm{ml}^{-1}$ when added to the fertilization wells. A $100 \mu \mathrm{l}$ aliquot of the sperm suspension was added to each $400 \mu \mathrm{l}$ well of fertilization TALP medium containing 50-70 COC which had been washed twice in Hepes-TALP medium and once in fertilization medium after maturation. Spermatozoa and COC were incubated together for $18-22 \mathrm{~h}$ under the same conditions as described for oocyte maturation.

After insemination, the remaining cumulus cells were removed by vortexing for $2 \mathrm{~min}$. The putative zygotes were washed three times in Hepes-buffered synthetic oviduct fluid (SOF) and placed in groups of 15-20 in 20 $\mu$ l SOF supplemented with essential and non-essential amino acids (Gibco Life Technologies, Paisley), $1 \mathrm{mmol}$ glutamine $\mathrm{l}^{-1}$ and $0.8 \%$ fatty-acid free BSA (SoFaaBSA; Gardner et al., 1994) under mineral oil in a humidified atmosphere of $5 \% \mathrm{O}_{2}, 5 \% \mathrm{CO}_{2}$ and $90 \% \mathrm{~N}_{2}$ at $39^{\circ} \mathrm{C}$.

The cultures were terminated at day 7 for all experiments on blastocysts. Only embryos with a well defined blastocoele were selected for labelling to eliminate sampling bias. Blastocyst rates were consistently $25-30 \%$ of total zygotes placed in culture.

\section{Selection of embryo stages}

Embryo stages from the two-cell to the hatched blastocyst stage were selected at the following times after fertilization (Van Soom et al., 1997): two-cell, $31 \mathrm{~h}$; four-cell, $38 \mathrm{~h}$; fiveto eight-cell, $49 \mathrm{~h}$; 9-16-cell, $100 \mathrm{~h}$; morula, $128 \mathrm{~h}$; early blastocyst, day 6; expanded blastocyst, day 7; hatched blastocyst, day 8 .

\section{Comparison of early and later cleaving embryos}

Zygotes that had completed the first cleavage division at $29 \mathrm{~h}$ after fertilization were moved to separate drops (15-20 
in $20 \mu 1)$. They were allowed to develop until day 7 . Total cell counts and apoptotic cell counts were made and compared with the remaining embryos that had not completed the first cleavage division at $29 \mathrm{~h}$ after fertilization.

\section{Addition of fetal bovine serum to culture medium}

When required, $10 \%$ warmed FBS was added to the embryo culture medium at approximately $45 \mathrm{~h}$ after fertilization. Three separate batches of FBS were used for the serum comparison study: batch 1, heat-inactivated FBS (JRH Biosciences, Lenexa, KS); batch 2, heat-inactivated FBS (Sigma); batch 3, FBS (Sera-Lab Ltd, Loughborough).

\section{TUNEL}

Day 7 embryos with intact zonae pellucidae were fixed and permeabilized as described for mouse embryos (Brison and Schultz, 1996) but with an increase in the duration of permeabilization in Triton-X100 to $180 \mathrm{~min}$. The embryos were washed twice in PBS-polyvinyl pyrrolidone (PBSPVP), $\mathrm{pH} 7.4$, and incubated in fluorescein-conjugated dUTP and TdT (TUNEL reagents; Boehringer Mannheim, Lewes) for $1 \mathrm{~h}$ at $37^{\circ} \mathrm{C}$ in the dark. Positive controls were incubated in DNAse 1 (1000 $\mathrm{U} \mathrm{ml}^{-1}$; Sigma), which cleaves all DNA, for $20 \mathrm{~min}$ at $37^{\circ} \mathrm{C}$, and washed twice before TUNEL. Negative controls were incubated in fluorescein-dUTP in the absence of TdT. After TUNEL, embryos were washed three times and counterstained with propidium iodide $\left(50 \mu \mathrm{g} \mathrm{m} \mathrm{m}^{-1}\right)$ after RNAse treatment ( $50 \mu \mathrm{g}$ RNAse for $60 \mathrm{~min}$ at room temperature) to label all nuclei.

\section{Fluorescence microscopy}

Labelled nuclei were examined with $\times 40$ or $\times 65$ immersion planeofluor objectives using a Zeiss Axioplan microscope fitted with epifluorescent illumination. Three standard filter sets were used: (i) for detection of fluorescein isothiocyanate (FITC) alone (emission wavelength: $525 \mathrm{~nm}$ ); (ii) for detection of propidium iodide alone (emission wavelength: $560 \mathrm{~nm}$ ); and (iii) a dual filter set for detection of both fluorochromes.

Blastocysts were analysed using a Biorad MRC 600 laserscanning confocal microscope according to the method of Brison and Schultz (1998) to confirm the distribution of TUNEL positive nuclei between the ICM and trophectoderm cell lineages.

\section{Cell counts}

Total number of cells and number of apoptotic dead cells were counted and dead cell indices were calculated by dividing the number of dead cells by the total number of cells, which included dead cells. Labelling and analysis were carried out blind on individual experimental groups of embryos.

\section{Statistical analysis}

All sets of experimental data were first tested for normality using a K-S goodness of fit test. Differences in blastocyst cell number and dead cell indices were compared using either an unpaired Student's $t$ test or a one-way ANOVA with least significant difference test. Differences among the percentage of embryos developing in culture were compared by chi-squared analysis. The SPSS (6) statistical package for Windows was used for all analyses. All culture experiments were performed on between three and five separate occasions.

\section{Results}

\section{Onset of apoptosis}

All stages of development from the two-cell to the hatched blastocyst stage were analysed by TUNEL for apoptotic cell death and propidium iodide for total cell counts (Fig. 1).

Consistent with other species, there was no evidence of apoptosis from the two- to the eight-cell stage. However, apoptosis occurred in bovine embryos of normal morphology at the 9-16-cell stage, in which $30 \%$ of all embryos had at least one dead cell. The dead cell index in this group was $4-6 \%$. Although embryos with between 9 and 16 cells were grouped together as one stage, it should be noted that apoptosis was greatest in nine-cell embryos.

A similar observation was made at the morula stage, in which almost $50 \%$ of embryos showed apoptotic cell death. Dead cell index decreased $(2.0-2.5 \%)$, but increased upon commencement of blastulation $(4 \%)$ and stayed relatively constant until hatching. Analysis of the percentage of embryos with either 0,1 or $\geq 2$ apoptotic nuclei revealed that the majority of blastocysts possessed at least one apoptotic nucleus.

\section{Extent and localization of apoptotic cell death in the blastocyst}

The total number of cells was compared with dead cell index for day 7 blastocysts. The overall trend indicated that the number of cells was negatively correlated with extent of apoptosis (Fig. 2). Blastocysts of a small number of cells $(<100$ cells) had dead cell indices ranging from 0 to almost $10 \%$, whereas the variability was lower in embryos of $>100$ cells $(0-6 \%)$.

The TUNEL reagents were capable of penetrating fixed permeabilized embryos as all nuclei of embryos treated with DNase I as a positive control showed uniform staining (data not shown). However, in embryos not treated with DNase I, a fragmented nuclear morphology characteristic of apoptosis was observed (Fig. 3a,b). On some occasions, TUNELnegative cells of fragmented morphology were observed in the propidium iodide channel. These cells were counted as apoptotic. Furthermore, as described in rat and mouse blastocysts, not all TUNEL-positive nuclei were in the process of fragmentation (Brison and Schultz, 1997; Pampfer et al., 1997).

The majority of apoptotic nuclei were located in the ICM 
(a)

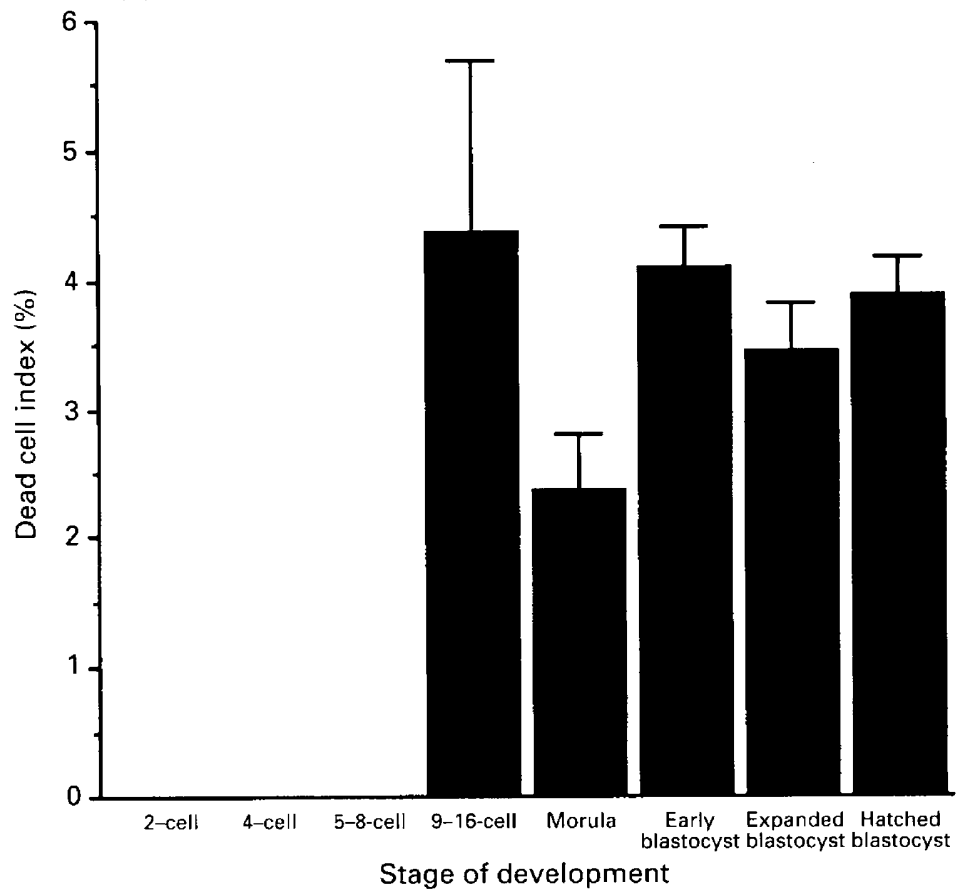

(b)

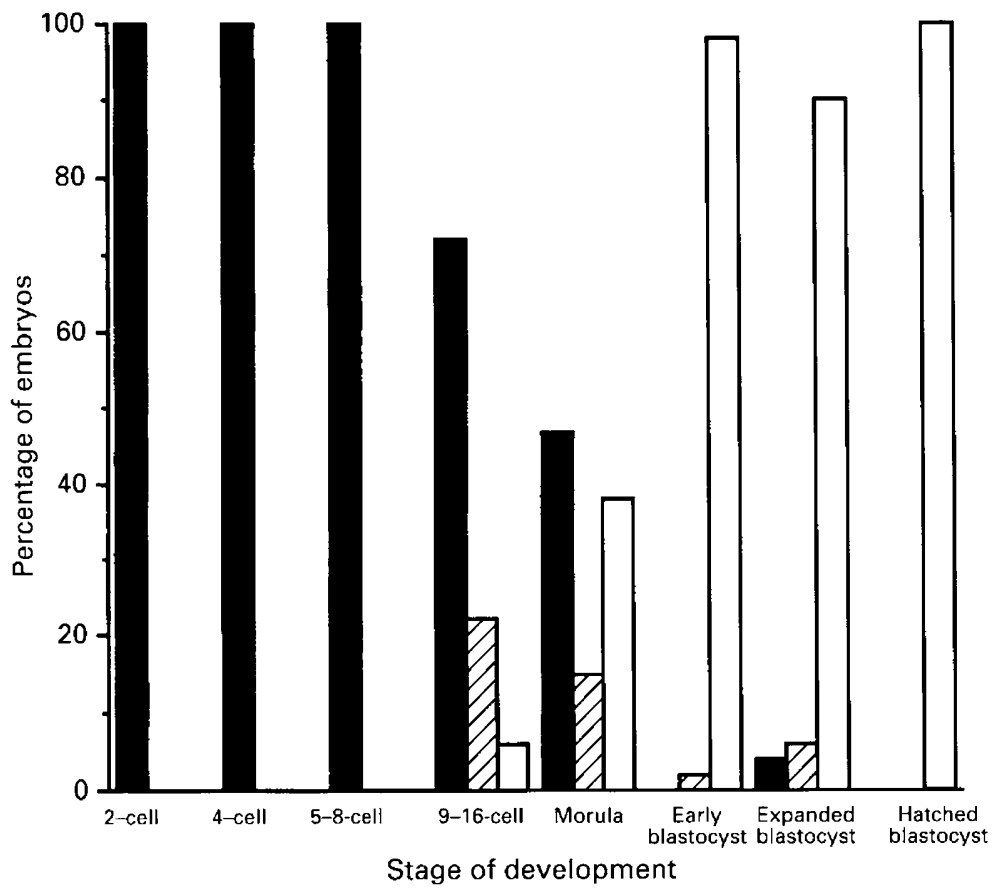

Fig. 1. Onset of apoptosis during development of bovine embryos. (a) Dead cell indices from the two-cell to the hatched blastocyst stage. Data are expressed as mean \pm SEM. (b) Percentage of embryos in (a) with ( $\square$ ) 0 , ( $\square$ ) 1 or $(\square) \geq 2$ apoptotic nuclei. The experiment was performed at least three times using a total of 45-50 embryos per stage.

region of the blastocyst as confirmed by confocal microscopy. However, evidence of nuclear fragmentation was visible in the trophectoderm and some apoptotic bodies had been extruded into the blastocoele cavity (Fig. 3).

\section{Effect of timing of first cleavage division}

Groups of blastocysts developing from zygotes that had completed the first cleavage division at $29 \mathrm{~h}$ after fertilization 


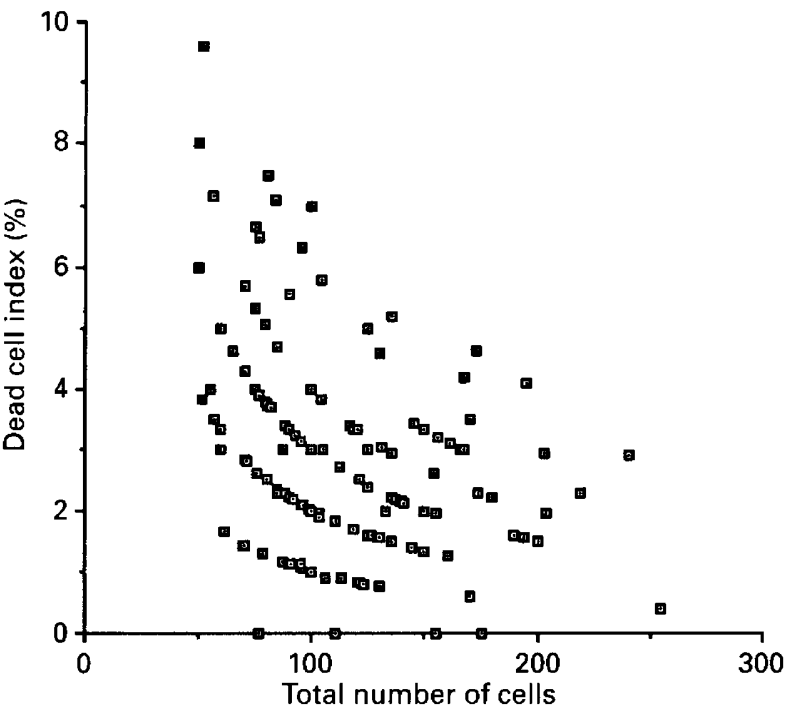

Fig. 2. Relationship between total number of cells and apoptotic dead cell index during development of bovine embryos. A total of 145 blastocysts produced over 6 months was analysed.

were compared with slower cleaving embryos to test for a possible relationship between rate of development and the subsequent extent of apoptosis (Table 1). Faster cleaving zygotes had significantly more cells $(P<0.01)$, significantly fewer apoptotic dead cells $(P<0.01)$ and better rates of development at the blastocyst stage $(P<0.05)$. The number of cells was normalized for the two groups and dead cell indices were compared again. This ensured that the difference in dead cell index observed was independent of the number of cells, as early cleaving embryos had more cells and, by default, a lower incidence of apoptosis (see above). A significant difference in dead cell index was still observed $(P<0.01)$.

\section{Effect of culturing embryos in the presence or absence of serum}

Groups of day 7 blastocysts that had developed in the absence of FBS had a significantly greater number of cells $(P<0.01)$ than any of the groups cultured in the presence of serum (Fig. 4a). Embryos grown without serum had a smaller dead cell index (Fig. 4b). Variation among individual serum batches was also observed; group 2 embryos (JRH Biosciences) had the smallest number of cells and the greatest dead cell index. There was no significant difference among blastocyst rates (25-28\%) for the four conditions.

\section{Discussion}

The results of the present study show that, in common with other mammalian species, cell proliferation in IVP bovine embryos is associated with apoptotic cell death and that the extent of apoptosis is affected by in vitro culture conditions. It should be emphasised that these data refer to IVP embryos. No measurements were made of apoptosis in in vivo embryos and it is possible that the results do not reflect the situation in vivo. Further work is required to clarify this matter.

Apoptosis was first observed at the 9-16-cell stage, in embryos of normal morphology. This was an unexpected observation, since in mouse embryos apoptosis does not occur in eight-cell embryos or morulae derived either in vivo or in vitro (Handyside and Hunter, 1986; Brison and Schultz, 1997). Similarly, Jurisicova et al. (1996) reported that in normal human embryos, from the two-cell to the uncompacted morula stage, TUNEL analysis combined with DAPI staining (to assess chromatin condensation and nuclear shape) was negative with regard to necrosis and apoptosis. However, Jurisicova et al. (1996) reported that from the two-cell stage onwards, fragmenting human embryos were dying by apoptosis. (The term fragmenting is used here to describe dead or dying embryos. It does not refer to the fragmentation of DNA as occurs in apoptosis but to the morphology of the whole embryo.) This was also reported in mouse embryo development, in which a wave of fragmentation was associated with apoptosis at the one-cell stage (Jurisicova et al., 1998). In this case, apoptosis may be related to activation of the embryonic genome. In mice and humans, the major events take place at the two- and four-cell stage, respectively. However, in mice, activation of the embryonic genome is initiated late in the first cell cycle (Schultz 1993), co-incident with the first observation of apoptosis in this species. The function of this wave of apoptosis may be to kill embryos that do not undergo appropriate activation of the embryonic genome. However, this does not explain the early expression of apoptosis in cows, as the embryos were neither fragmenting nor abnormal. The simultaneous activation of apoptotic cell death and the embryonic genome at the 9-16-cell stage may, when necessary, eliminate non-viable cells in the developing embryo. This proposal is supported by the high variation in the extent of apoptosis at this time. It would be of interest to correlate apoptosis with transcription of early markers of activation of the embryonic genome in individual blastomeres.

A marked increase in the incidence of apoptosis was apparent after the onset of blastulation. Most embryos $(90-100 \%)$ showed some cell death from the early to the hatched blastocyst stage compared with earlier stages. Apoptotic index was inversely related to the number of blastocyst cells, indicating that after initial activation, cell death decreased with blastocyst expansion. Most apoptosis appeared to be present in the ICM. These observations are similar to those in mouse and human blastocysts (Hardy, 1997) and are consistent with apoptosis serving a physiological histogenetic function (Handyside and Hunter, 1986). As murine blastocyst development progresses, ICM cells lose their ability to regenerate trophectoderm (Handyside, 1978). It is possible that in the late stage ICM, apoptosis reaches a certain threshold to prevent the formation of ectopic trophectoderm in the incipient germ layers (Pierce et al., 1989; Parchment, 1991, 1993). In the present study, in IVP bovine blastocysts, apoptosis was observed predominantly in the ICM and not in the 

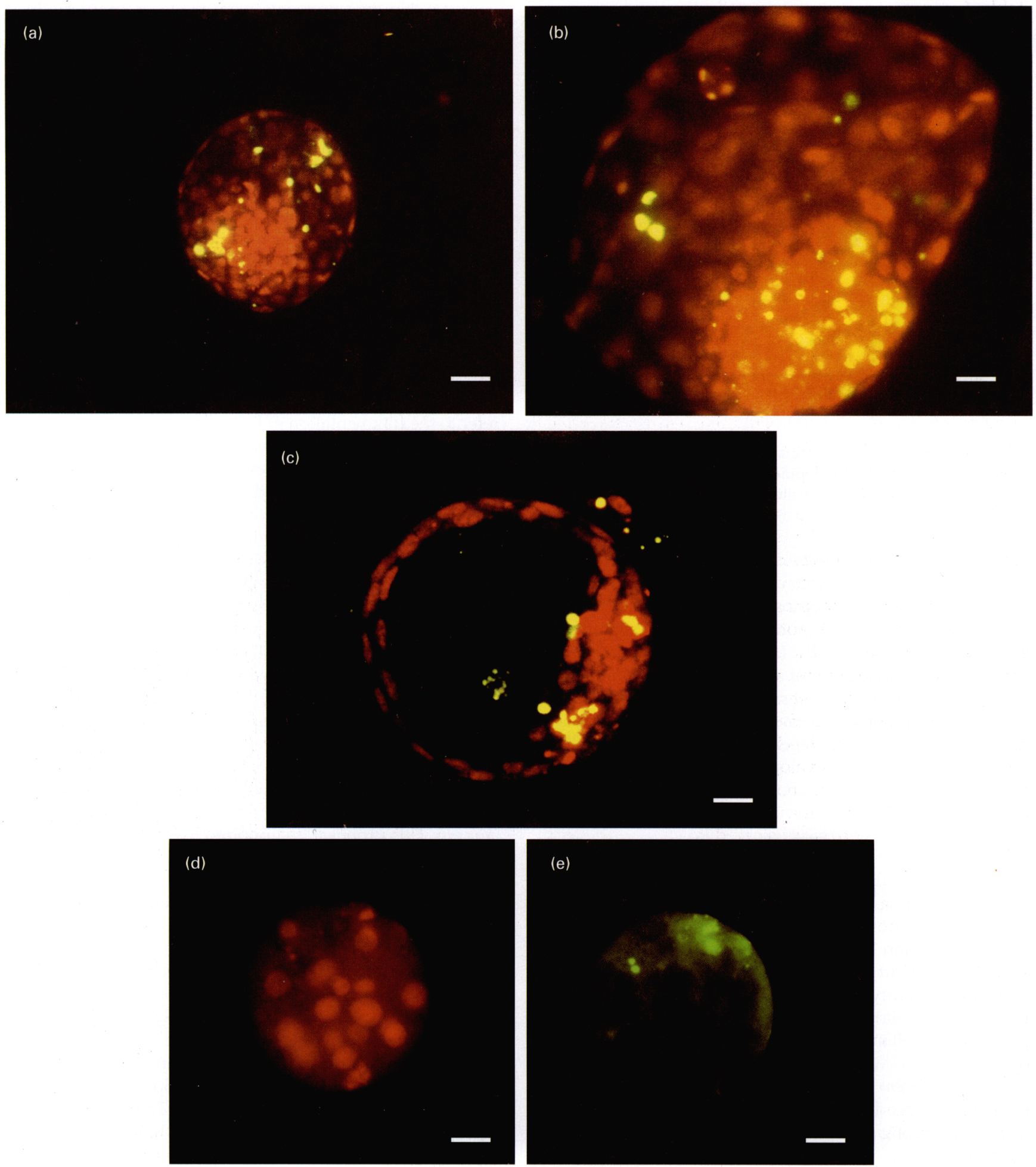

(e)

Fig. 3. Detection of apoptotic and all nuclei in bovine embryos by TLNEL (fluroscein isothiocyanate-conjugated dUTP; green channel) and propidium iodide (red channel), respectively. (a) Day 7 expanded blastocyst showing labelling in both channels. (b) Day 8 hatched blastocyst showing apoptotic nuclei in the inner cell mass (ICM) and also extruded into the blastocoele. (c) Confocal section through day 7 blastocyst confirming most of the apoptotic nuclei are in the ICM. (d,e) 18 -cell embryo shown in the red (d) and green (e) channels showing apoptotic nuclear morphology. Scale bars represent $(\mathrm{a}, \mathrm{d}, \mathrm{e}) 25 \mathrm{~m}$ and $(\mathrm{b}, \mathrm{c}) 15 \mu \mathrm{m}$. 
Table 1. Number of cells, dead cell index and blastocyst rates for day 7 bovine embryos that completed the first cleavage division at $29 \mathrm{~h}$ after fertilization (early cleaving) compared with slower cleaving embryos (late cleaving)

\begin{tabular}{lrr}
\hline Parameter & Early cleaving* $^{*}$ & Late cleaving $^{* *}$ \\
\hline Number of cells (mean \pm SEM) & $107.7 \pm 5.3$ & $85.65 \pm 4.3^{\mathrm{a}}$ \\
Dead cell index $(\%)$ & $3.0 \pm 0.3$ & $14.9 \pm 0.4^{\mathrm{b}}$ \\
Normalized dead cell index $(\%)$ & $3.5 \pm 0.3$ & $4.5 \pm 0.4^{\mathrm{c}}$ \\
Blastocyst rates $(\%)$ & 24.2 & $11.2^{\mathrm{d}}$ \\
\hline
\end{tabular}

${ }^{*}$ Measured on four occasions; $n=57$, mean \pm SEM.

**Measured on four occasions; $n=40$, mean \pm SEM.

abc $P<0.01 ; \mathrm{d} P<0.05$

trophectoderm. IVP blastocysts from other species appear to lack such regulation; apoptosis is distributed randomly in both ICM and trophectoderm (humans: Hardy et al., 1989; mice: Jurisicova et al., 1998). Cultured blastocysts lacking the transforming growth factor $\alpha$ (TGF- $\alpha)$ gene also show extensive apoptosis outside the ICM (Brison and Schultz, 1998). The mechanism for regulation of apoptosis in the trophectoderm is currently unclear.

Apoptosis may also be related to 'embryo quality'. Although it is not possible to measure the number of blastocyst cells before embryo transfer, it is thought that embryos with a large number of cells are more likely to implant and give rise to live offspring (Van Soom et al., 1997). The results of the present study show that blastocysts consisting of a small number of cells and hence possibly of reduced developmental potential, have a high and variable incidence of apoptosis. It has been suggested that when programmed cell death reaches a certain threshold, it is detrimental to further development (Jurisicova et al., 1996; Hardy, 1997) thus eliminating potentially non-viable offspring. Similarly, in humans and cows, the timing of the first cleavage division is considered to be a useful noninvasive method for the selection of good quality embryos for transfer (Shoukir et al., 1997; Van Soom et al., 1997). For example, in humans, significantly more clinical pregnancies were obtained from embryos that had completed the first cleavage division at $25 \mathrm{~h}$ after fertilization (Shoukir et al., 1997). Comparison of the extent of apoptosis between early and late cleaving bovine embryos also indicates that in the late cleaving and thus less viable embryos, a nonphysiological incidence of cell death may result in decreased developmental competence.

Addition of serum to the culture medium has an effect on bovine and ovine embryo morphology (Gardner et al., 1994), ultrastructure (Dorland et al., 1994; Thompson et al., 1995), metabolism (Thompson et al., 1996) and post-implantation development (Walker et al., 1992). It has also been implicated in the enlarged offspring syndrome (Thompson ef al., 1995). Culture in the presence of serum affects the developmental kinetics of embryos leading to premature blastulation (Walker et al., 1992a,b). Contrary to the findings of Van Langendonckt ct al. (1997), the results of the present study show for the first time that the total number of cells is decreased and the incidence of apoptosis is increased in the presence of FBS. Furthermore, the extent to which this occurs
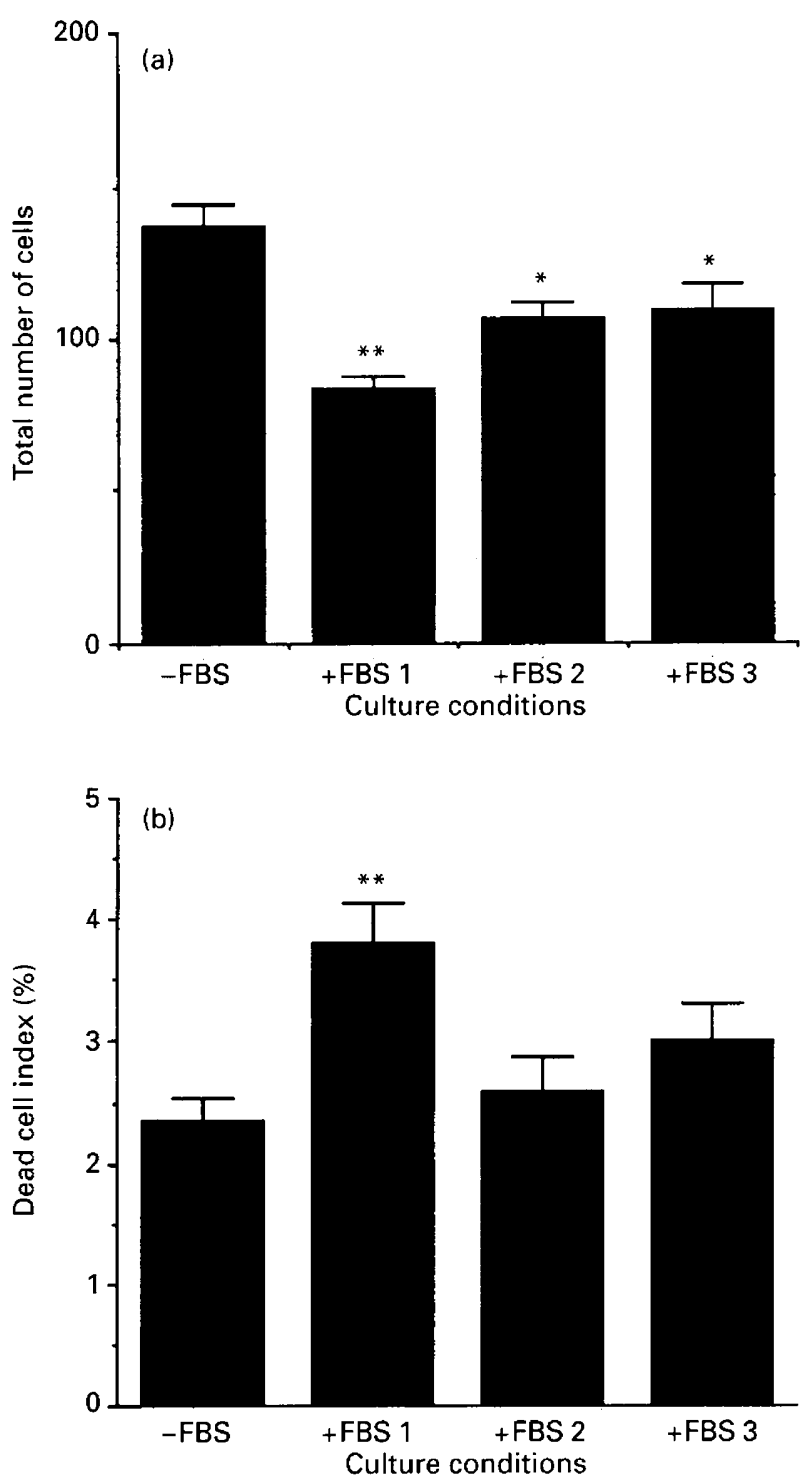

Fig. 4. Effect of addition of $10 \%$ fetal bovine serum (FBS) on (a) total number of cells and (b) dead cell index during development of bovine embryos. -FBS $(n=29)$, control; FBS $1(n=53)$, heatinactivated FBS (JRH Biosciences, Lenexa, KS); FBS $2(n=22)$, heat-inactivated FBS (Sigma); FBS $3(n=41)$, FBS (Sera-Lab Ltd, Loughborough). The experiment was performed over 13 individual culture weeks and was repeated a minimum of three times for each condition. ${ }^{*} P<0.05,{ }^{*} P<0.01$ compared with - FBS control.

varies with individual batches of serum, a fact that emphasises the problems of using complex media. Heat inactivation of FBS played no role in determining rates of apoptosis. Further clarification of the effect of FBS on the total number of cells is required. FBS contains a variety of constituents, such as peptide growth factors, which can act as survival factors in cmbryos (Brison and Schultz, 1997, 1998), but may also contain factors that can trigger apoptosis, such as the cytokine, tumour necrosis factor (TNF).

It has been suggested that embryo culture in the presence of serum affects the distribution of cells between the trophectoderm and the ICM. An increase in the 
trophectoderm:ICM cell ratio may lead to an imbalance in placental and fetal size and observed pathological postnatal phenotype (Leese et al., 1998). Alternatively, apoptosis may act to maintain ICM fidelity by ridding the embryo of aberrant cells, thus any alteration in the extent of cell death could potentially affect the future development of the fetus.

This work was supported by the European Union and a studentship from the University of York to A. T. Byrne. The authors wish to thank E. Ferguson and C. Hall for their help with in vitro embryo production.

\section{References}

Brison DR and Schultz RM (1996) RT-PCR-based method to localise the spatial expression of genes in the mouse blastocyst Molecular Reproduction and Development 44 171-178

Brison DR and Schultz RM (1997) Apoptosis during mouse blastocyst formation: evidence for a role for survival factors including TGF- $\alpha$ Biology of Reproduction 56 1088-1096

Brison DR and Schultz RM (1998) Increased incidence of apoptosis in transforming growth factor $\alpha$-deficient mouse blastocysts Biology of Reproduction 59 136-144

Byrne AT, Brison DR, Southgate J and Leese HJ (1998) Journal of Reproduction and Fertility Abstract Series 2118

Copp AJ (1978) Interaction between inner cell mass and trophectoderm of the mouse blastocyst Journal of Embryology and Experimental Morphology 48 $109-125$

Dorland M, Gardner DK and Trounson AO (1994) Serum in synthetic oviduct fluid causes mitochondrial degeneration in ovine embryos journal of Reproduction and Fertility Abstract Series 1370

El-Shershaby AM and Hinchliffe AR (1974) Cell redundancy in the zonaintact preimplantation mouse blastocyst: a light and microscope study of dead cells and their fate Journal of Embryology and Experimental Morphology 31 643-654

Enders AC and Schlafke S (1981) Differentiation of the blastocyst of the rhesus monkey American Journal of Anatomy 162 1-21

Enders AC, Hendrickx AG and Binkerd PE (1982) Abnormal development of blastocysts and blastomeres in the rhesus monkey Biology of Reproduction 26 353-366

Enders AC, Lantz KC and Schlafke S (1990) Differentiation of the inner cell mass of the baboon blastocyst Anatomical Records 226 237-248

Frei RE, Schultz GA and Church RB (1989) Qualitative and quantitative changes in protein synthesis occur at the 8-16 cell stage of embryogenesis in the cow Journal of Reproduction and Fertility 86 637-641

Gardner DK, Lane M, Spitzer A and Batt PA (1994) Enhanced rates of cleavage and development for sheep zygotes cultured to the blastocyst stage in vitro in the absence of serum and somatic cells: amino acids, vitamins and culturing embryos in groups stimulate development Biology of Reproduction 50 390-400

Gavrieli Y, Sherman Y and Ben-Sasson SA (1992) Identification of programmed cell death in situ via specific labelling of DNA fragmentation Journal of Cell Biology 119 493-501

Giles JR and Foote RH (1995) Rabbit blastocyst: allocation of cells to the inner cell mass and trophectoderm Molecular Reproduction and Development 41 204-211

Handyside AH (1978) Time of commitment of inside cells isolated from preimplantation mouse embryos Journal of Embryology and Experimental Morphology 45 37-53

Handyside AH and Hunter S (1986) Cell division in the mouse blastocyst before implantation Roux's Archives of Developmental Biology 195519-526

Hardy K (1997) Cell death in the mammalian blastocyst Molecular Human Reproduction 3919-925

Hardy K and Handyside AH (1996) Metabolism and cell allocation during parthenogenetic mouse preimplantation development Molecular Reproduction and Development 43313-322

Hardy K, Handyside AH and Winston RML (1989) The human blastocyst: cell number, death and allocation during late preimplantation development in vitro. Development 107 597-604

Hardy K, Warner A, Winston RML and Becker DL (1996) Expression of intercellular junctions during preimplantation development of the human embryo Molecular Human Reproduction 2 621-632

Hurst PR, Jeffries K, Eckstein P and Wheeler AG (1978) An ultrastructural study of preimplantation uterine embryos of the rhesus monkey Journal of Anatomy 126 209-220

Jurisicova A, Varmuza S and Casper RF (1996) Programmed cell death and human embryo fragmentation Molecular Human Reproduction 293-98

Jurisicova A, Rogers I, Fasciani A, Casper RF and Varmuza S (1998) Effects of maternal age and conditions of fertilization on programmed cell death during murine preimplantation embryo development Molecular Human Reproduction 4 139-145

Kerr JF, Wyllie AH and Currie AR (1972) Apoptosis: a basic biological phenomenon with wide ranging implications in tissue kinetics British Journal of Cancer 26 239-257

Lea RG, McCracken JE, McIntyre SS, Smith W and Baird JD (1996) Disturbed development of the preimplantation embryo in the insulindependant diabetic BB/E rat Diabetes 45 1463-1470

Leese HJ, Donnay I and Thompson JG (1998) Human assisted conception: a cautionary tale. Lessons from domestic animals Human Reproduction 13 Supplement 4 184-202

Lopata A, Kohlman DJ and Kellow GN (1982) The fine structure of human blastocysts developed in culture. In Embryonic Development Part B: Cellular Aspects pp 69-85 Eds R Alan. Liss, New York

Lu KH, Gordon I, Gallager M and McGovern H (1987) Pregnancy established in cattle by transfer of embryos derived from in vitro fertilisation of oocytes matured in vitro. Veterinary Records 121 259-260

Mohr LR and Trounson AO (1982) Comparative ultrastructure of hatched human, mouse and bovine blastocysts journal of Reproduction and Fertility 66 499-504

Pampfer S, De Hertogh R, Vanderheyden I, Michiels B and Vercheval M (1990a) Decreased inner cell mass proportion in blastocysts from diabetic rats Diabetes 102 793-803

Pampfer S, Vanderhayden I, Michiels B and De Hertogh R (1990b) Cell allocation to the inner cell mass and the trophectoderm in rat embryos during in vivo preimplantation development Roux's Archives of Developmental Biology 198 257-263

Pampfer S, Vanderheyden I, McCracken J, Vasela J and De Hertogh R (1997) Increased cell death in rat blastocysts exposed to maternal diabetes in utero and to high glucose or tumour necrosis factor- $\alpha$ in vitro. Development 124 $4827-4836$

Papaioannou VE and Ebert KM (1988) The preimplantation pig embryo: cell number and allocation to trophectoderm and inner cell mass of the blastocyst in vivo and in vitro. Development 102 793-803

Parchment RE (1991) Programmed cell death (apoptosis) in murine blastocysts: extracellular free radicals, polyamines and other cytotoxic agents In Vivo 5 493-500

Parchment RE (1993) The implications of a unified theory of programmed cell death, polyamines, oxyradicals, and histogenesis in the embryo International Journal of Developmental Biology 37 75-83

Pierce GB, Lewellyn AL and Parchment RE (1989) Mechanism of programmed cell death in the blastocyst Proceedings National Academy of Science USA 86 3654-3658

Potts DM and Wilson IB (1967) The preimplantation conceptus of the mouse at 90 hours post-coitum Journal of Anatomy 102 1-11

Schultz RM (1993) Regulation of zygotic gene activation in the mouse Bioessays 15 531-538

Shoukir Y, Campana A, Farley T and Sakkas D (1997) Early cleavage of in vitro fertilized human embryos to the 2-cell stage: a novel indicator of embryo quality and viability Human Reproduction 12 1531-1536

Sible JC, Anderson JA, Lewellyn AL and Maller JL (1997) Zygotic transcription is required to block a maternal programme of apoptosis in Xenopus embryos Developmental Biology 189 335-346

Thompson JG, Pugh PA, Tervit HR and Berg DK (1992) In vitro production of domestic animals: advances made at Ruakura, New Zealand Australian Biotechnology 2 280-287

Thompson JG, Gardner DK, Pugh PA, McMillan WH and Tervit HR (1995) Lamb birth weight is affected by culture system utilised during in vitro preelongation development of ovine embryos Biology of Reproduction 53 1385-1391

Thompson JG, Bell CS and Tervit HR (1996) Utilisation of [1-14-C]-pyruvate by day-6 ovine blastocysts derived from in vivo or in vitro sources Proceedings of the International Congress for Animal Reproduction, Sydney 3 $22-24$

Downloaded from Bioscientifica.com at 04/26/2023 01:43:34PM 
Van Langendonckt A, Donnay I, Schuurbiers N, Auquier P, Carolan C, Massip A and Dessy F (1997) Effects of supplementation with fetal calf serum on development of bovine embryos in synthetic oviductal fluid medium Journal of Reproduction and Fertility 109 87-93

Van Soom A, Ysebaert M and De Kruif A (1997) Relationship between timing of development, morula morphology and cell allocation to the inner cell mass and trophectoderm in in vitro produced embryos Molecular Reproduction and Development 47 47-56

Walker SK, Heard TM and Seamark RF (1992a) In vitro culture of sheep embryos without co-culture: successes and perspectives Theriogenology 37 $111-126$
Walker SK, Heard TM, Bee CA, Frensham AB, Warnes DM and Seamark RF (1992b) Culture of embryos from farm animals. In Embryonic Development and Manipulation in Animal Production pp 111-120 Eds A Lauria and F Gandolfi. Portland Press, London

Warner CM, McElhinny AS, Wu L, Cieluch C, Ke X, Cao W, Tang C and Exley GE (1998) Role of the Ped gene and apoptosis in control of preimplantation development Journal of Assisted Reproduction and Genetics 15 331-337

Weil M, Jacobson MD, Coles HS, Davies TJ, Gardner RL, Raff KD and Raff KC (1996) Constitutive expression of the machinery for programmed cell death Journal of Cell Biology 133 1053-1059 